\title{
PELANGGARAN ETIKA BIROKRASI DALAM PEMERINTAHAN DI INDONESIA
}

\author{
Bureaucratic Ethics Violation in Government in Indonesia
}

\author{
Lies Kumara Dewi \\ Fakultas Ilmu Sosial Dan Ilmu Politik, Universitas Sang Bumi Ruwa Jurai \\ lieskumaradewi13@gmail.com
}

\begin{abstract}
In government ethics, there is a prevailing assumption that through the appreciation of good ethics, an apparatus will be able to build a commitment to make himself an example of goodness and maintain government morality. Good government officials and have high morals, will always guard themselves in order to avoid disgraceful acts, because they are called to maintain the mandate given, through imaging the behavior of daily life. Within the scope of the government profession, for example, there are certain values that must be upheld in order to maintain the image of a government capable of carrying out its duties and functions.

Trends or symptoms that arise today, many bureaucratic apparatus in carrying out their duties often violate the rules of the game that have been set. Cases related to ethical violations in the government bureaucracy such as corruption and gratification (bribery) involve many professions in violating ethics such as state administration officials, regional heads, legislators, prosecutors, judges, police, tax officials, and so on.

Bureaucratic Ethics is part of the rules of the game in the Bureaucracy or Civil Service organization which structurally has regulated the rules of the game, which we know as. Code of Ethics for Civil Servants, which has been regulated by the Civil Service Act. To be more effective in delivering the code of ethics, the code of ethics can be read together -the same on certain occasions which is sometimes followed by a discourse from a ceremonial leader called a ceremonial inspector, the intention is to create favorable moral conditions in experienced organizations and to cultivate the necessary mental attitude, as well as to create good morals. The Code of Ethics is usually read in flag ceremonies, monthly ceremonies or ceremonies anniversary of the organization concerned, and national ceremonies.

In order to create a more ethical Bureaucratic Apparatus according to the above expectations, it is necessary to make efforts and training in that direction as well as to enforce strict and clear sanctions for those who violate the code of ethics regardless of their rank and position. Anyone who violates the code of ethics, whether it's superiors or subordinates, must be dealt with firmly to create a deterrent effect. Therefore, in relation to the Code of Ethics for Civil Servants, it must really animate, appreciate and implement the employment rules that have been determined or set as the rules of the game for the Bureaucratic apparatus.
\end{abstract}

Keywords: bureaucratic ethics, government

\begin{abstract}
ABSTRAK
Dalam etika pemerintahan, terdapat asumsi yang berlaku bahwa melalui penghayatan etika yang baik, seorang aparatur akan dapat membangun komitmen untuk menjadikan dirinya sebagai teladan tentang kebaikan dan menjaga moralitas pemerintahan. Aparatur pemerintahan yang baik dan bermoral tinggi, akan senantiasa menjaga dirinya agar dapat terhindar dari perbuatan tercela, karena ia terpanggil untuk menjaga amanah yang diberikan, melalui pencitraan perilaku hidup sehari-hari. Dalam lingkup profesi pemerintahan misalnya, ada nilai-nilai tertentu yang
\end{abstract}


harus tetap ditegakkan demi menjaga citra pemerintah yang mampu menjalankan tugas dan fungsinya.

Kecenderungan atau gejala yang timbul dewasa ini banyak aparat birokrasi dalam pelaksanaan tugasnya sering melanggar aturan main yang telah ditetapkan. Kasus yang berhubungan dengan pelanggaran etika dalam birokrasi pemerintahan seperti korupsi dan gratifikasi ( suap ) banyak melibatkan beberapa profesi dalam melakukan pelanggaran terhadap etika seperti pejabat administrasi negara, kepala daerah, anggota legislatif, jaksa, hakim, kepolisian, pegawai perpajakan, dan lain sebagainya.

Etika Birokrasi merupakan bagian dari aturan main dalam organisasi Birokrasi atau Pegawai Negeri yang secara struktural telah diatur aturan mainnya, dimana kita kenal sebagai

Kode Etik Pegawai Negeri, yang telah diatur lewat Undang-undang Kepegawaian. Untuk lebih efektif dalam penyampaian kode etik maka kode etik itu dapat dibaca secara bersama -

sama pada kesempatan tertentu yang kadang-kadang diikuti oleh suatau wejangan dari seorang pimpinan upacara disebut inspektur upacara , maksudnya adalah untuk menciptakan kondisikondisi moril yang menguntungkan dalam organisasi yang berpengalaman dan mempertumbuhkan sikap mental yang diperlukan, juga untuk menciptakan moral yang baik. Kode Etik tersebut biasanya dibaca dalam upacara bendera, upacara bulanan atau upacara ulang tahun organisasi yang bersangkutan, dan upacara - upacara nasional.

Agar tercipta Aparat Birokrasi yang lebih beretika sesuai harapan di atas, maka perlu usaha dan latihan ke arah itu serta penegakkan sangsi yang tegas dan jelas kepada mereka yang melanggar kode Etik tanpa memandang pangkat dan jabatannya. Siapapun yang melanggar kode etik, entah itu atasan ataupun bawahan harus ditindak dengan tegas untuk menimbulkan efek jera. Oleh karena itu dalam hubungannya dengan Kode Etik Pegawai Negeri maka harus betul-betul menjiwai, menghayati dan melaksanakan aturan-aturan kepegawaian yang telah ditentukan atau ditetapkan sebagai aturan main para aparat Birokrasi.

Kata Kunci: etika birokrasi, pemerintahan

\section{Pendahuluan}

$\begin{array}{cccc}\text { Dalam suatu masyarakat } & \text { agar } \\ \text { hubungan } & \text { antar manusia } & \text { dapat } \\ \text { terlaksana } & \text { sebagaimana } & \text { yang }\end{array}$
diharapkan, maka dirumuskan etika atau norma-norma masyarakat. Oleh karena itu nilai-nilai etika yang hidup dan berlaku dalam suatu masyarakat, bukanlah sekedar menjadi keyakinan pribadi bagi para anggotanya, akan tetapi juga menjadi seperangkat norma yang terlembagakan. Dengan kata lain, suatu nilai etika atau norma harus menjadi acuan dan pedoman berperilaku yang membawa akibat dan pengaruh secara moral. Dalam etika pemerintahan, terdapat asumsi yang berlaku bahwa melalui penghayatan etika yang baik, seorang aparatur akan dapat membangun komitmen untuk menjadikan dirinya sebagai teladan tentang kebaikan dan menjaga moralitas pemerintahan. Aparatur pemerintahan yang baik dan bermoral tinggi, akan senantiasa menjaga dirinya agar dapat terhindar dari perbuatan tercela, karena ia terpanggil untuk menjaga amanah yang diberikan, melalui pencitraan perilaku hidup sehari-hari. Dalam lingkup profesi pemerintahan misalnya, ada nilai-nilai tertentu yang harus tetap ditegakkan demi menjaga citra pemerintah yang mampu menjalankan tugas dan fungsinya.

Berbicara tentang pelanggaran etika birokrasi dewasa ini menjadi topik yang sangat menarik dibahas, terutama dalam mewujudkan aparatur yang bersih dan berwibawa. Kecenderungan atau gejala yang timbul dewasa ini banyak aparat birokrasi dalam pelaksanaan tugasnya sering melanggar aturan main yang telah ditetapkan. Etika Birokrasi dalam penyelenggaraan 
pemerintahan sangat terkait dengan moralitas dan mentalitas aparat birokrasi dalam melaksanakan tugastugas pemerintahan itu sendiri yang tercermin lewat fungsi pokok pemerintahan, yaitu fungsi pelayanan, fungsi pengaturan atau regulasi dan fungsi pemberdayaan masyarakat. Jadi berbicara tentang Etika Birokrasi berarti kita berbicara tentang bagaimana aparat Birokrasi tersebut dalam melaksanakan fungsi tugasnya sesuai dengan ketentuan aturan yang seharusnya dan semestinya, yang pantas untuk dilakukan dan yang sewajarnya dimana telah ditentukan atau diatur untuk ditaati dilaksanakan. Kasus yang berhubungan dengan pelanggaran etika dalam birokrasi pemerintahan seperti yang disebutkan di atas melibatkan beberapa profesi dalam melakukan pelanggaran terhadap etika seperti pejabat administrasi negara, kepala daerah, anggota legislatif, jaksa, hakim, kepolisian, pegawai perpajakan, dan lain sebagainya.

Dari Korps Adyaksa, beberapa waktu yang lalu terdapat kasus santer tentang penyuapan jaksa Urip Tri Gunawan yang menerima suap sebesar 660 ribu dolar AS atau lebih dari Rp. 6 Miliar dari Arthalita Suryani. Kemudian berita kasus suap yang melanda Kepala Kejaksaan Tinggi DKI Jakarta Sudung Situmorang dan Asisten Tindak Pidana Khusus Kejaksaan Tinggi DKI Tomo Sitepu disebut sebagai penerima suap dari direksi PT Brantas Abipraya. Tujuan pemberian suap agar kejaksaan menghentikan penyelidikan dugaan tindak pidana korupsi yang dilakukan Sudi Wantoko. Korupsi itu diduga merugikan negara sebesar $\mathrm{Rp} 7$ miliar. Selain dari itu Kasus suap panitera terbaru terjadi pada saat penyidik KPK melakukan operasi tangkap tangan terhadap panitera pengganti Pengadilan Negeri Jakarta Pusat Muhammad Santoso dan staf konsultan hukum Wiranatakusumah bernama Ahmad Yani, yang diduga memberikan uang 28 dolar Singapura kepada Santoso. Adapun uang tersebut berasal dari Raoul Adhitya Wiranatakusumah, pengacara PT Kapuas Tunggal Persada, yang ingin memenangkan gugatan dari PT Mitra Maju Sukses.

Sebagai catatan, sebelum operasi itu berlangsung, pada hari yang sama majelis hakim memberi putusan yang memenangkan pihak tergugat, yaitu PT Kapuas Tunggal Persada. Dan yang baru-baru ini kita dengar adalah kasus suap di Pengadilan Negeri Medan yaitu Hakim ad hoc Pengadilan Tindak Pidana Korupsi yaitu Merry Purba yang dituntut 9 ( Sembilan ) tahun penjara dan denda Rp 350 juta subside 3 bulan kurungan. Merry sebelumnya diduga menerima suap sebesar $\operatorname{Sin} \$ 280$ ribu dari Tamin selaku terdakwa korupsi penjualan tanah yang masih berstatus asset Negara (CNN Indonesia, 25 April 2019) dan masih banyak kasus-kasus lagi yang kita baca baik di media massa maupun elektronik yang melibatkan korps Adyaksa tersebut. Hal ini menunjukkan betapa pelanggaran etika penegak hukum sudah sangat memprihatinkan sampai-sampai kasuskasus dapat dipermainkan untuk memenangkan perkara demi uang walaupun kasus tersebut merugikan masyarakat. Oleh karena itu, wajar bila dalam masyarakat timbul suatu sikap pesimis yang mengatakan bahwa hukum di Indonesia tumpul keatas dan runcing ke bawah. Dan itu merupakan suatu kasus yang harus menjadi koreksi penegakan hukum di Indonesia dan terutama dalam bidang korupsi, kolusi dan nepotisme yang rentan terhadap kasus penyuapan.

Dilain pihak pelanggaran etika juga banyak menimpa anggota legislatif seperti kaus suap untuk meng-goal-kan 
proyek-proyek tertentu maupun pelanggaran etika yang merusak citra moral karena untuk menguntungkan diri pribadi manupun golongan. Contoh beberapa waktu yang lalu, seperti kasus "Papa minta saham" oleh Setya Novanto yang pada saat itu menjabat sebagai Ketua DPR RI. Kemudian seperti yang dikatakan oleh Ketua KPK Agus Raharjo kepada wartawan yang dilansir detik.com Jumat (6/9/2019) bahwa Pelaku pejabat public terbanyak dalam perkara korupsi adalah para anggota DPR dan DPRD yaitu 255 perkara. Padahal sebagai seorang ketua DPRatau anggota DPR yang notabene wakil rakyat sangat tidak pantas dengan adanya kasus tersebut.

Dalam bidang eksekutif, terdapat beberapa kepala daerah yang tersandung kasus korupsi, yaitu berjumlah 110 perkara, termasuk di Provinsi Lampung, seperti Bupati Tanggamus, Bupati Lampung Selatan dan Bupati Lampung Tengah serta baru baru ini Bupati Lampung Utara. Ratu Atut Chosiyah, Gubernur Banten yang tersangkut kasus pengadaan alat kesehatan dan dugaan suap terkait penanganan sengketa pilkasa Lebak, Banten, kemudian Gubernur Sumatera Utara yang tersandung kasus korupsi Dana Bantuan Sosial (Bansos), Bantuan Daerah Bawahan (BDB) dan Bantuan Operasional Sekolah (BOS) dll.

Pihak-pihak yang terlibat dalam kasus-kasus yang terjadi di dalam konteks etika berasal dari seluruh elemen pemerintahan baik eksekutif, legislatif maupun yudikatif. Padahal pejabat pemerintah baik eksekutif, legislatif maupun yudikatif harus mematuhi etika jabatannya masingmasing. Etika dalam birokrasi pemerintahan merupakan hal yang sangat penting untuk keberlangsungan penyelenggaraan pemerintahan dan untuk menjaga citra birokrasi agar birokrasi pemerintahan terus mendapat kepercayaan dari masyarakat.

\section{Permasalahan}

Yang menjadi permasalahan sekarang ini bagaimana proses penentuan Etika dalam Birokrasi itu sendiri, siapa yang akan mengukur seberapa jauh etis atau tidak, bagaimana dengan kondisi saat itu dan tempat daerah tertentu yang mengatakan bahwa itu etis saja di daerah kami atau dapat dibenarkan, namun ditempat lain belum tentu. Dapat dikatakan bahwa Etika Birokrasi sangat terpergantung dari seberapa jauh melanggar di tempat atau daerah mana, kapan dilakukannya dan pada saat yang bagaimana, serta sangsi apa yang akan diterapkan sangsi sosial moral ataukah sangsi hukum, semua ini sangat temporer dan bervariasi di negara kita sebab terkait juga dengan aturan, norma, adat dan kebiasaan setempat.

\section{Pembahasan}

Dalam bahasa Indonesia "Etika" berarti "kesusilaan" yang terdiri dari bahasa Sanskerta "Su" yang berarti baik, dan "Sila" yang berarti norma atau dasar kehidupan. Etika berkaitan dengan tingkah laku manusia untuk bertindak secara benar. Jadi etika selalu condong pada perbuatan baik.

Prof. Dr. Muh. Said menjelaskan bahwa Secara etimologis etika berasal dari perkataan Yunani "Etos" yang berarti adat atau watak. Kata ini identik dengan asal kata moral dari bahasa latin "Mos" (Jamaknya adalah Mores) yang juga berarti adat atau cara hidup. Jadi kedua kata tersebut ( etika dan Moral) menunjukkan cara berbuat yang menjadi adat karena persetujuan atau praktek sekelompok manusia. Dengan demikian etika dapat di artikan sebagai suatu sikap kesediaan jiwa seseorang untuk senantiasa taat dan patuh kepada 
seperangkat

peraturan-peraturan

kesusilaan.

Dilain pihak dalam penentuan suatu etika baik dalam birokrasi itu sendiri maupun dalam masyarakat, siapa yang mengukurnya suatu pelanggaran etika atau norma dikatakan etis atau tidak sangat tergantung dari aturan, norma, adat dan kebiasaan masyarakat setempat. Menurut Soerdjono Soekanto, norma-norma dalam masyarakat itu sendiri mempunyai kekuatan mengikat yang berbeda-beda. Ada norma yang lemah, yang sedang sampai yang terkuat daya ikatnya. Untuk dapat membedakan kekuatan norma-norma tersebut, secara sosiologis dikenal adanya 4 (empat) pengertian yaitu:

\section{Cara (usage)}

2. Kebiasaan (folkways)

3. Tata Kelakuan (Mores)

4. Adat- istiadat (custom)

Cara (usage) menunjuk pada suatu bentuk perbuatan. Norma ini mempunyai kekuatan yang sangat lemah bila dibandingkan dengan norma yang lain. Cara (usage) lebih menonjol dalam hubungan antar individu dalam masyarakat. Suatu penyimpangan terhadapnya tidak akan mengakibatkan hukuman yang berat, akan tetapi sekedar celaan dari individu lainnya, contoh cara makan, cara minum dll.

Kebiasaan (Folkways) mempunyai kekuatan mengikat yang lebih besar daripada cara. Kebiasaan diartikan sebagai perbuatan yang diulang-ulang dalam bentuk yang sama, yang merupakan bukti bahwa orang banyak menyukai perbuatan tersebut, contoh kebiasaan menghormat kepada orang yang lebih tua.

Tata Kelakuan ( Mores) adalah apabila kebiasaan tersebut tidak sematamata dianggap kebagai cara berperilaku saja tetapi bahkan diterima sebagai norma pengatur maka kebiasaan tadi disebut sebagai tata kelakuan (more). Tata kelakuan ini pada sebagian masyarakat memaksa untuk mematuhinya apabila ada anggota masyarakat yang melanggarnya maka dianggap melanggar norma yang ada sehingga anggota masyarakat harus mematuhi tata kelakuan (mores) tersebut.

Adat-istiadat (custom) ini merupakan norma yang paling kuat / tinggi mengikatnya. Suatu pelanggaran terhadapnya akan menderita sanksi yang keras. Adat istiadat berasal dari tata kelakuan (mores) yang kekal serta kuat integrasinya dengan pola perilaku masyarakat maka lama kelamaan menjadi adat-istiadat, contoh adanya hukum adat yang melarang terjadinya perceraian. Dalam ini tidak hanya yang bersangkutan tercemar namanya, tetapi seluruh keluarga dan bahkan seluruh sukunya .

Norma-norma tersebut diatas setelah mengalami suatu proses yang dinamakan proses pelembagaan (institutionalization) yaitu suatu proses yang dilewati oleh suatu norma yang baru untuk menjadi bagian dari salah satu norma yang ada di masyarakat yang dikenal, diakui, dihargai dan kemudian ditaati dalam kehidupan sehari-hari. Dengan sendirinya, selain mengetahui maka seharusnya manusia juga memahami mengapa ada etika / norma yang mengatur kehidupan bersama dengan orang lain atau dalam kelompok. Artinya di dalam berperilaku manusia terikat oleh batas-batas tertentu yang tidak boleh dilanggar. Apabila batas-batas tersebut dilanggar maka orang yang bersangkutan akan dihukum.

Aristoteles juga memberikan istilah Ethica yang meliputi dua pengertian yaitu etika meliputi 
Kesediaan dan Kumpulan peraturan, yang mana dalam bahasa Latin dikenal dengan kata Mores yang berati kesusilaan, tingkat salah saru perbuatan (lahir, tingkah laku), Kemudian perkataan Mores tumbuh dan berkembang menjadi Moralitas yang mengandung arti kesediaan jiwa akan kesusilaan. (Haryanto, 2012, Hal 8-9). Dengan demikian maka Moralitas mempunyai pengertian yang sama dengan Etika atau sebaliknya, dimana kita berbicara tentang Etika Birokrasi tidak terlepas dari moralitas aparat Birokrasi penyelenggara pemerintahan itu sendiri.

Etika dan moralitas secara teoritis berawal dari pada ilmu pengetahuan (cognitive) bukan pada efektif. Moralitas berkaitan pula dengan jiwa dan seamangat kelompok masyarakat. Moral terjadi bila dikaitkan dengan masyarakat, tidak ada moral bila tidak ada masyarakat dan seyogyanya tidak ada masyarakat tanpa moral, dan berkaitan dengan kesadaran kolektif dalam masyarakat. Immanuel Kant, teori moralitas tidak hanya mengenai hal yang baik dan yang buruk, tetapi menyangkut masalah yang ada dalam kontak social dengan masyarakat, ini berarti Etika tidak hanya sebatas moralitas individu tersebut dalam artian aparat birokrasi tetapi lebih dari itu menyangkut perilaku di tengah-tengah masyarakat dalam melayani masyarakat apakah sudah sesuai dengan aturan main atau tidak, apakah etis atau tidak.

Dari beberapa pendapat yang menegaskan tentang pengertian Etika di atas jelaslah bagi kita bahwa Etika terkait dengan moralitas dan sangat tergantung dari penilaian masyarakat setempat, jadi dapat dikatakan bahwa moral merupakan landasan normative yang didalamnya mengandung nilai-nilai moralitas itu sendiri dan landasan normative tersebut dapat pula dinyatakan sebagai Etika yang dalam Organisasi Birokrasi disebut sebagai Etika Birokrasi.

Dengan melihat paparan diatas mengenai pelanggaran etika birokrasi dalam penyelenggaran pemerintahan maka kita dapat melihat kenyataan bahwa apa yang masyarakat inginkan jauh dari harapan, maka tentulah hal ini sangat menimbulkan kekecewaan dalam masyarakat. Para aparat birokrasi yang seharusnya mementingkan kepentingan rakyat, justru sebaliknya mencari keuntungan pribadi dan golongan. Dalam etika atau norma masyarakat yang berlaku bahwa seorang aparatur birokrasi harus amanah dalam memegang tampuk kekuasaan untuk memperjuangkan kepentingan rakyat. Rakyat menginginkan pemimpin yang jujur, amanah dan dapat dipercaya. Itulah etika atau norma yang berlaku dalam masyarakat Indonesia. Akan tetapi etika dan norma tersebut banyak dilanggar oleh aparat birokrasi itu sendiri. Proyek - proyek dengan nilai ratusan miliar atau bahkan triliuan rupiah dipotong untuk kepentingan sejumlah pejabat yang mereka sebut sebagai " commitment fee ". Padahal seharusnya uang rakyat Indonesia yang menjadi sumber utama anggaran, harus dapat dinikmati secara penuh oleh masyarakat. Niat baik pemerintah untuk membangun negeri ini diselewengkan oleh para pelaku korupsi " kata ketua KPK Agus Raharjo yang banyak menanggani kasus-kasus korupsi tersebut. Inilah protret etika birokrasi kita ketika masyarakat mengharapkan agar para aparatur Birokrasi bekerja dengan penuh rasa tanggungjawab, kejujuran dan keadilan dijunjung, sementara yang kenyataan yang terjadi mereka yang melanggar Etika Birokrasi sama sekali tidak bermoral atau beretika, maka disitulah kita mengharapkan adanya aturan yang dapat ditegakkan yang menjadi norma 
atau rambu-rambu dalam melaksanakan tugasnya. Sesuatu yang kita inginkan itu adalah Etika yang yang perlu diperhatikan oleh aparat Birokrasi tadi.

Ada beberapa alasan mengapa Etika Birokrasi penting diperhatikan dalam pengembangan pemerintahan yang efisien, tanggap dan akuntabel, menurut Agus Dwiyanto, bahwa : Pertama masalah - masalah yang dihadapi oleh birokrasi pemerintah dimasa mendatang akan semakin kompleks. Modernitas masyarakat yang semakin meningkat telah melahirkaan berbagai masalah - masalah publik yang semakin banyak dan komplek dan harus diselesaikan oleh birokrasi pemerintah. Dalam memecahkan masalah yang berkembang birokrasi seringkali tidak dihadapkan pada pilihan - pilihan yang jelas seperti baik dan buruk. Para pejabat birokrasi seringkali tidak dihadapkan pada pilihan yang sulit, antara baik dan buruk, yang masing - masing memiliki implikasi yang saling berbenturan satu sama lain. Misalnya dalam kasus pembebasan tanah terkadang pilihan yang dihadapi oleh para pejabat birokrasi seringkali bersifat dikotomis dan dilematis. Mereka harus memilih antara memperjuangkan program pemerintah dan memperhatikan kepentingan masyarakatnya.

Kedua, keberhasilan pembangunan yang telah meningkatkan dinamika dan kecepatan perubahan dalam lingkungan birokrasi. Dinamika yang terjadi dalam lingkungan tentunya menuntut kemampuan birokrasi untuk melakukan adjustments agar tetap tanggap terhadap perubahan yang terjadi dalam lingkungannya. Kemampuan untuk bisa melakukan adjustment itu menuntut discretionary power yang besar. Penggunaan kekuasaan direksi ini hanya akan dapat dilakukan dengan baik kalau birokrasi memiliki kesadaran dan pemahaman yang tinggi mengenai besarnya kekuasaan yang dimiliki dan implikasi dari penggunaan kekuasaan itu bagi kepentingan masyarakatnya. Kesadaran dan pemahaman yang tinggi mengenai kekuasaan dan implikasi penggunaan kekuasaan itu hanya dapat dilakukan melalui pengembangan etika birokrasi.

Walaupun pengembangan etika birokrasi sangat penting bagi pengembangan birokrasi namun belum banyak usaha dilakukan untuk mengembangkannya. Sejauh ini baru lembaga peradilan dan kesehatan yang telah maju dalam pengembangan etika, seperti terefleksikan dalam etika kedokteran dan peradilan. Etika ini dapat menjadi salah satu sumber tuntunan bagi para professional dalam pelaksanaan pekerjaan mereka. Pengembangan etika birokrasi ini tentunya menjadi satu tantangan bagi para sarjana dan praktisi administrasi publik dan semua pihak yang menginginkan. Dari alasan yang dikemukakan di atas ada sedikit gambaran bagi kita mengapa Etika Birokrasi menjadi suatu tuntutan yang harus sesegera mungkin dilakukan sekarang ini, hal tersebut sangat terkait dengan tuntutan tugas dari aparat birokrasi itu sendiri yang seiring dengan semakin komplesnya permasalahan yang ada dalam masyarakat dan seiring dengan fungsi pelayanan dari Birokrat itu sendiri agar dapat diterima dan dipercaya oleh masyarakat yang dilayani, diatur dan diberdayakan.

Untuk itu para Birokrat harus merubah sikap perilaku agar dapat dikatakan lebih beretika atau bermoral di dalam melaksanakan tugas dan fungsinya, dengan demikian harus ada aturan main yang jelas dan tegas yang perlu ditaati yang menjadi landasan 
dalam bertindak dan berperilaku di tengah-tengah masyarakat.

Di negara kita yang masih kental budaya paternalistik atau tunduk dan taat kepada Bapak atau pemimpin pemerintahan yang juga merupakan pemimpin birokrasi, sehingga sangat sulit bagi masyarakat untuk menegur para pemimpin Birokrasi bahwa yang dilakukannya itu tidak etis atau tidak bermoral, mereka lebih banyak diam dan malah manurut saja melihat perilaku yang ada dalam jajaran aparat birokrasi.

Dalam kondisi seperti di atas, inisiatif penetapan Etika bagi aparat Birokrasi atau penyelenggara pemerintahan hampir sepenuhnya berada di tangan pemerintah. Dimana pemerintah atau organisasi yang disebut birokrasi merasa paling berkuasa dan merasa dialah yang mempunyai kewenangan untuk menentukan sesuatu itu etis atau tidak bagi dirinya menurut versi atau pandangannya sendiri, tanpa mempedulikan apa yang aturan main di dalam masyarakat. Permasalahan ini sangat rumit karena Etika Birokrasi cenderung diseragamkan melalui peraturan Kepegawaian yang telah diatur dari Birokrasi tingkat atas atau pemerintah pusat, sementara dalam pelaksanaan tugasnya dia berada di tengah-tengah masyarakat, yang jadi pertanyaan sekarang apakah yang dikatakan Etis menurut peraturan kepegawaian yang mengatur Aparat Birokrasi dapat dapat dikatakan Etis pula dalam masyarakat ataupun sebaliknya.

Etika Birokrasi merupakan bagian dari aturan main dalam organisasi Birokrasi atau Pegawai Negeri yang secara struktural telah diatur aturan mainnya, dimana kita kenal sebagai Kode Etik Pegawai Negeri, yang telah diatur lewat Undang-undang Kepegawaian. Untuk lebih efektif dalam penyampaian kode etik maka kode etik itu dapat dibaca secara bersama - sama pada kesempatan tertentu yang kadang-kadang diikuti oleh suatau wejangan dari seorang pimpinan upacara disebut inspektur upacara , maksudnya adalah untuk menciptakan kondisi-kondisi moril yang menguntungkan dalam organisasi yang berpengalaman dan mempertumbuhkan sikap mental yang diperlukan, juga untuk menciptakan moral yang baik. Kode Etik tersebut biasanya dibaca dalam upacara bendera, upacara bulanan atau upacara ulang tahun organisasi yang bersangkutan, dan upacara - upacara nasional.

Pegawai Negeri Sendiri adalah setiap warga negara Republik Indonesia yang telah memenuhi syarat yang ditentukan, diangkat oleh pejabat yang berwenang dan diserahi tugas dalam suatu jabatan negara atau diserahi tugas negara lainnya, dan digaji berdasarkan peraturan perundangundangan yang berlaku.

Setiap organisasi, misalnya PNS atau TNI dan lain-lain ada usaha untuk membentuk Kode Etik yang lebih mengikat atau mengatur anggotanya agar lebih beretika dan bermoral. Namun sampai sekarang belum diketahui sampai seberapa jauh dan juga belum dapat dipantau secara jelas dari perbuatan seseorang apakah yang bersangkutan melanggar Etika atau Kode Etik atau tidak, karena belum jelas batasannya dan apa sangsinya, sehingga benar-benar dapat dipergunakan sebagai ukuran atau criteria untuk menilai perilaku atau tingkah laku aparat Birokrasi sehingga disebut beretika atau tidak.

Tetapi apapun dan bagaimanapun maksud yang hendak dicapai dengan membentuk, menanamkan Kode Etik tersebut adalah demi terciptanya Aparat Birokrasi lebih jujur, lebih bertanggung 
jawab, lebih berdisiplin, dan lebih rajin serta yang terpenting lebih memiliki moral yang baik terhindar dari perbuatan tercela seperti korupsi, kolusi, nepotisme dan lain-lain.

Agar tercipta Aparat Birokrasi yang lebih beretika sesuai harapan di atas, maka perlu usaha dan latihan ke arah itu serta penegakkan sangsi yang tegas dan jelas kepada mereka yang melanggar kode Etik tanpa memandang pangkat dan jabatannya. Siapapun yang melanggar kode etik, entah itu atasan ataupun bawahan harus ditindak dengan tegas untuk menimbulkan efek jera. Oleh karena itu dalam hubungannya dengan Kode Etik Pegawai Negeri maka harus betul-betul menjiwai, menghayati dan melaksanakan aturanaturan kepegawaian yang telah ditentukan atau ditetapkan sebagai aturan main para aparat Birokrasi.

\section{Penutup}

Etika Birokrasi merupakan hal yang sangat penting dan harus diimplementasikan kepada para aparat birokrasi pemerintah agar tercipta aparat yang jujur, bersih dan berwibawa sesuai dengan aturan - aturan yang telah ditetapkan dalam kode etik birokrasi. Walaupun dalam kenyataan sekarang hal-hal tersebut hanya merupakan konsep ideal yang diharapka dari aparat pelaksana pemerintahan di Indonesia yang merupakan aparat birokrasi di negara kita yang mempunyai tugas dan fungsi pokok untuk melayani masyarakat, mengatur masyarakat dan memberdayakan masyarakat. Fungsifungsi ini dapat dilaksanakn dengan baik apabila Aparat Birokrasi tersebut memiliki Etika dalam bekerja.

Etika Birokrasi bukan hanya sekedar retorika yang didengungkan saja melalui Undang-undang atau Peraturan Pemerintah Tentang kepegawaian, tetapi lebih dari itu bagaimana ketentuan-ketentuan tersebut dapat dihayati dan diamalkan dalam berperilaku sebagai Aparat Birokrasi dan yang tidak kalah penting yaitu bagaimana penegakkan hukum atau sangsi yang tegas bagi para pelanggar aturan yang telah disepakati dan ditentukan tersebut. Hukuman atau sangsi perlu ditegakkan secara merata tanpa pandang bulu apakah dia atasan atau bawahan semuanya harus sama di mata hukum.

Masyarakat juga berhak menentukan kode Etik atau aturan dalam masyarakat yang juga turut mengatur keberadaan seorang Aparat Birokrasi di lingkungannya, kalau memang melanggar harus ada komitmen bersama untuk mentaati aturan yang ada di tengah-tengah masyarakat. Jadi yang disebut Etika Birokrasi merupakan norma aturan yang melekat pada anggota atau aparat Birokrasi itu sendiri di manapun dan kapan dia berada, baik di kantor maupun di tengah-tengah masyarakat.

\section{DAFTAR PUSTAKA}

Agus Dwiyanto, Pemerintah Yang Baik, Tanggap, Efisien, dan Akuntabel, Kontrol atau Etika, Seminar Forum Kebijakan Publik, Pasca Sarjana, UGM, Yogyakarta, 2000.

Inu Kencana Syafiie, Etika Pemerintahan, Bandung, Rineka Cipta, 1994.

Haryanto, Drs, MA, Makalah Etika Pemerintahan, Staf Pengajar Jurusan Ilmu Pemerintahan FISIPOL, UGM, Yogyakarta. hal. 8,9 .

Muhammad Said. Etika Masyarakat Indonesia. Jakarta, Pradnya Pramita 1960, halaman 23. 
Soerdjono Soekanto, Sosiologi Suatu Pengantar, Rajawali, Jakarta, 2006.

Haryantousia.blogspot.co.id./2012/11/Et

ika Birokrasi Dalam

Penyelenggaraan Pemerintahan Di

Indonesia (Analisis PP No : 53

Tahun 2010). 